\title{
A fatal forensic intoxication with fenarimol: analysis by HPLC/DAD/MSD
}

\author{
P. Proença ${ }^{a, *}$, E. Pinho Marques ${ }^{\mathrm{a}, \mathrm{b}}, \mathrm{H}$. Teixeira ${ }^{\mathrm{a}, \mathrm{b}}$,

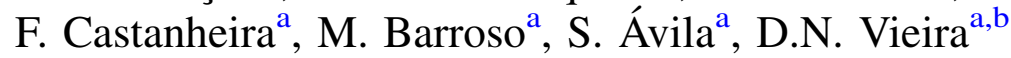 \\ ${ }^{a}$ National Institute of Legal Medicine-Delegation of Coimbra, Largo da Sé Nova, 3000-213 Coimbra, Portugal \\ ${ }^{\mathrm{b}}$ Faculty of Medicine, University of Coimbra, Largo da Sé Nova, 3000-213 Coimbra, Portugal
}

Received 26 August 2002; received in revised form 29 November 2002; accepted 17 January 2003

\begin{abstract}
Fenarimol $\left(\right.$ Rubigan $\left.^{\mathbb{R}}\right)$ is a pyrimidine ergosterol biosynthesis inhibitor used as a systemic fungicide. The authors present a fatal fenarimol intoxication case analysed in the Forensic Toxicology Service of the National Institute of Legal Medicine. The results were used to compare two different HPLC techniques, regarding selectivity and sensitivity: an HPLC system with a diode array detector (DAD) and an HPLC system with a DAD and a mass spectrometry detector (MSD) with an electrospray interface. All biological samples were submitted to a solid-phase extraction procedure. The detection and quantification limits of fenarimol, linearity, precision and accuracy were evaluated. The fenarimol concentration levels determined were of $89.0 \mathrm{mg} / \mathrm{ml}$ in gastric contents, $1.9 \mathrm{mg} / \mathrm{g}$ in liver and $0.4 \mathrm{mg} / \mathrm{g}$ in kidney. Blood was not available at autopsy. No published data related to fenarimol self-poisoning were found, so it was not possible to interpret the results obtained by comparison with toxic/lethal levels.
\end{abstract}

(C) 2003 Elsevier Science Ireland Ltd. All rights reserved.

Keywords: Fenarimol; Fatal forensic intoxication; HPLC/PDA/MSD

\section{Introduction}

Fenarimol (2,4'-dicloro- $\alpha$-(pyrimidin-5-yl) benzhydryl alcohol) [1], commercially denominated by Rubigan ${ }^{\circledR}$, is an ergosterol biosynthesis inhibitor. It is used in agriculture, in doses of $120 \mathrm{~g} / \mathrm{l}$, as a systemic fungicide [2]. The compound is photochemically unstable, and is readily broken down by sunlight $[1,3-5]$. Fenarimol has shown reproductive, teratogenic, and oncogenic effects in experimental animals. It inhibits testosterone aromatase activity, which could result in an irreversible infertility in male rats [6-8]. Accidental human exposition could lead to, among others, eye irritation with corneal injury, skin irritation, nauseas, vomits and diarrhoea [9]. The lethal dose for an individual of $70 \mathrm{~kg}$ is estimated to be $28-500 \mathrm{~g}$ [10]. However, no reports on fatal cases have been published so far.

\footnotetext{
* Corresponding author. Tel.: +351-239854230.

E-mail address: paulaproenca@dcinml.mj.pt (P. Proença).
}

This work aimed at designing and validating in terms of linearity and recovery a method for the determination of fenarimol concentrations in liver, kidney and gastric content samples by HPLC/DAD/MSD.

\section{Case report}

A 46-year-old policeman was found, face down, in water surface inside an agricultural barrage. Close to the victim was found a pack of Bladan $^{\mathbb{R}}$, a common commercial name of parathion, an organophosphorus pesticide. The victim was under psychiatric treatment for depression. The autopsy report suggested intoxication with organophosphorus pesticides due to the presence of a strange scent in vomit and gastric content. The postmortem findings also indicated generalized visceral congestion and sero-mucous sanguine suffusion. No signs of violence were observed. Drowning was suggested as another possible cause of death. The autopsy was performed 3 days after the probable date of death. Biological samples received 
for toxicological analysis were stomach and its content, liver and kidney. The pack of Bladan ${ }^{\circledR}$ was also submitted to analysis.

\section{Material and methods}

\subsection{Chemicals}

All solvents were analytical or HPLC grade and were purchased from E. Merck (Darmstadt, Germany). Water was purified by a Milli-Q system obtained from Millipore (Molsheim, France). The fungicides fenarimol and ethirimol (used as internal standard) were supplied by Riedel-deHaën (Seelze, Germany). Each standard compound was dissolved in acetonitrile to perform a $1 \mathrm{mg} / \mathrm{ml}$ solution and stored at $4{ }^{\circ} \mathrm{C}$. The solid-phase extraction columns were Bond Elut Certify ${ }^{\mathbb{B}}$ LRC obtained from Varian (Harbor City, USA), and were used on a solid-phase system Vac Elut EPS 24, Varian. The $\mathrm{K}_{2} \mathrm{CO}_{3}$ buffer ( $\mathrm{pH} 9.5$ ) was prepared by dissolving $13.8 \mathrm{~g}$ of $\mathrm{K}_{2} \mathrm{CO}_{3}$ into a $100 \mathrm{ml}$ volumetric flask and bringing to volume with deionised water. The buffer was stored refrigerated $\left(4^{\circ} \mathrm{C}\right)$. Acetic acid solution $(0.1 \mathrm{M})$ was prepared by adding $57.2 \mu \mathrm{l}$ of glacial acetic acid $(d=1.05 \mathrm{~g} / \mathrm{l}, m=60.05 \mathrm{~g})$ into a $100 \mathrm{ml}$ volumetric flask and bringing to volume with deionised water. Control and calibration samples were prepared by spiking drug-free blood, liver and kidney postmortem samples with standard solutions.

\subsection{Instrumentation}

The chromatographic system used was a Waters 2690 Alliance System under software Millennium ${ }^{32}$ v. 4.0 (Milford, USA) and a Symmetry ${ }^{\circledR} \mathrm{C}_{18}(2.1 \times 150 \mathrm{~mm}$ i.d., $3.5 \mu \mathrm{m})$. The mobile phase consisted of a mixture of acetonitrile and water $(60: 40, \mathrm{v} / \mathrm{v})$ at a flow rate of $0.250 \mathrm{ml} / \mathrm{min}$.
The separation was performed at $30{ }^{\circ} \mathrm{C}$. The injection volume was $2.5 \mu \mathrm{l}$.

Detection employed a Waters 996 photodiode array detector (DAD) operated in the $210-400 \mathrm{~nm}$ wavelength passband with a $1.2 \mathrm{~nm}$ resolution. The UV absorbance was measured at $225 \mathrm{~nm}$.

Mass spectrometry detection (MSD) was carried out by a Waters ZQ 2000 mass spectrometer piloted using Millennium $^{32}$ v. 4.0 software and operated in the positive ionization mode in the $m / 0180-380$ mass range, with a scan time of $1 \mathrm{~s}$ and an interscan delay of $0.2 \mathrm{~s}$. The mass spectra were represented in the centroid mode. The main other instrumental settings were: capillary voltage $3.5 \mathrm{kV}$; cone voltage $25 \mathrm{~V}$; extractor $6 \mathrm{~V}$; ion energy 0.1 ; source temperature $80{ }^{\circ} \mathrm{C}$; desolvation temperature $110{ }^{\circ} \mathrm{C}$; cone gas $\left(\mathrm{N}_{2}\right)$ flowrate $50 \mathrm{l} / \mathrm{h}$ and desolvation gas $\left(\mathrm{N}_{2}\right)$ flowrate $250 \mathrm{l} / \mathrm{h}$.

\subsection{Sample preparation}

Blood, liver and kidney samples ( $1 \mathrm{ml}$ or $1 \mathrm{~g}$ ) and gastric content $(0.5 \mathrm{ml})$ were homogenized in deionised water $(4 \mathrm{ml})$. One millilitre of a $\mathrm{K}_{2} \mathrm{CO}_{3}$ buffer $(\mathrm{pH} 9.5)$ and $20 \mu \mathrm{l}$ of ethirimol, internal standard, $(1 \mathrm{mg} / \mathrm{ml})$ were added to each sample and centrifuged at $2000 \mathrm{~g}$ for $15 \mathrm{~min}$. Supernatants from these specimens were extracted by solid-phase extraction using Bond Elut Certify $^{\mathbb{R}}$ LRC columns, previously conditioned with $5 \mathrm{ml}$ methanol, $3 \mathrm{ml}$ deionised water and $1 \mathrm{ml}$ of $0.1 \mathrm{M}$ acetic acid. After a $5 \mathrm{~min}$ drying step under vacuum, $2 \mathrm{ml}$ $n$-hexane were applied to the column. Samples were deposited on the columns which were subsequently washed with $1 \mathrm{ml}$ deionised water. After drying under vacuum for $10 \mathrm{~min}$, elution was carried out with $3 \mathrm{ml}$ of $n$-hexane/ethyl acetate $(1: 1, \mathrm{v} / \mathrm{v})$. The eluate was collected into a conical glass tube and evaporated to dryness under a nitrogen stream $\left(40{ }^{\circ} \mathrm{C}\right)$. The residue was reconstituted in

\section{Auto-Scaled Chromatogram}

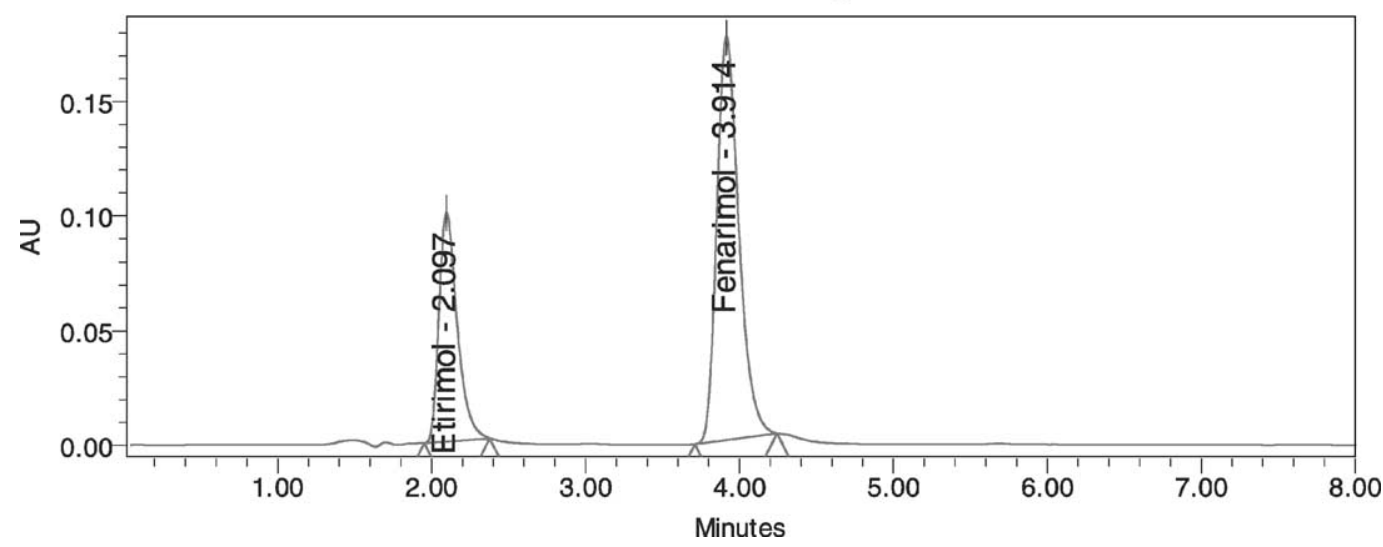

Fig. 1. Chromatogram obtained from a postmortem liver specimen spiked with fenarimol at $50 \mu \mathrm{g} / \mathrm{g}$ and ethirimol at $20 \mu \mathrm{g} / \mathrm{g}$ followed by DAD detection, at $225 \mathrm{~nm}$. 
Match Plot

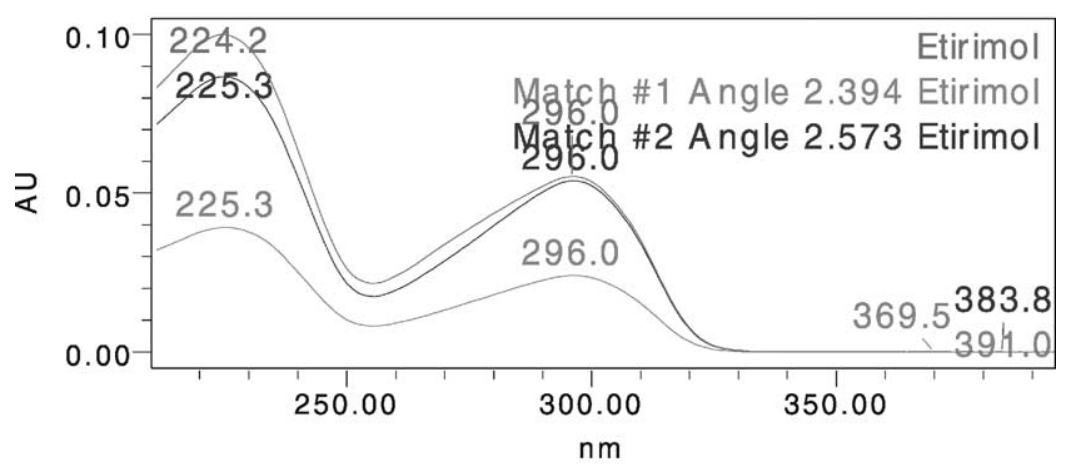

Match Plot

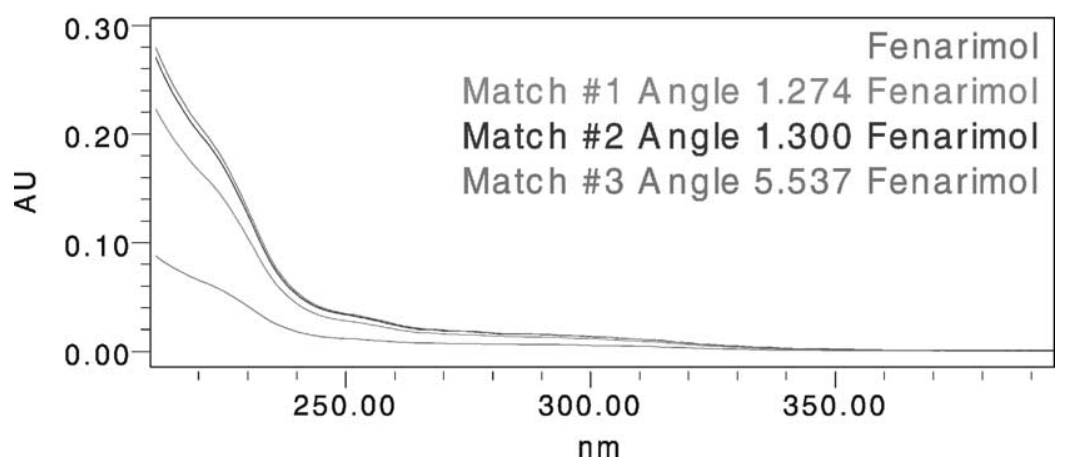

Fig. 2. UV spectral comparison of extracted fenarimol and ethirimol with a library obtain from a methanolic standard.

Table 1

Within-day precision and accuracy of fenarimol determination in blood, liver and kidney postmortem samples $(n=5)$

\begin{tabular}{|c|c|c|c|}
\hline $\begin{array}{l}\text { Spiked concentration } \\
(\mu \mathrm{g} / \mathrm{ml} \text { or } \mu \mathrm{g} / \mathrm{g})\end{array}$ & $\begin{array}{l}\text { Measured concentration } \\
(\text { mean } \pm \text { S.D. })(\mu \mathrm{g} / \mathrm{ml} \text { or } \mu \mathrm{g} / \mathrm{g})\end{array}$ & Precision (\%CV) & Accuracy $(\%)$ \\
\hline \multicolumn{4}{|l|}{ Blood } \\
\hline 5 & $4.83 \pm 0.271$ & 5.6 & 96.60 \\
\hline 10 & $9.91 \pm 0.158$ & 1.6 & 99.10 \\
\hline 20 & $19.23 \pm 0.169$ & 0.9 & 96.15 \\
\hline 100 & $98.65 \pm 1.127$ & 1.1 & 98.65 \\
\hline 250 & $247.90 \pm 1.925$ & 0.8 & 99.16 \\
\hline \multicolumn{4}{|l|}{ Liver } \\
\hline 5 & $4.72 \pm 0.195$ & 4.1 & 94.40 \\
\hline 10 & $9.50 \pm 0.154$ & 1.6 & 95.00 \\
\hline 20 & $18.52 \pm 0.527$ & 2.8 & 92.60 \\
\hline 100 & $96.77 \pm 1.840$ & 1.9 & 96.77 \\
\hline 250 & $240.45 \pm 4.418$ & 1.8 & 96.18 \\
\hline \multicolumn{4}{|l|}{ Kidney } \\
\hline 5 & $3.78 \pm 0.173$ & 4.6 & 75.60 \\
\hline 10 & $8.20 \pm 0.176$ & 2.1 & 82.00 \\
\hline 20 & $17.34 \pm 0.577$ & 3.3 & 86.70 \\
\hline 100 & $82.20 \pm 1.155$ & 1.4 & 82.20 \\
\hline 250 & $242.29 \pm 10.702$ & 4.4 & 96.92 \\
\hline
\end{tabular}


$1 \mathrm{ml}$ of methanol, and an aliquot $(2.5 \mu \mathrm{l})$ was injected in the HPLC system.

\section{Results and discussion}

Since intoxication by an organophosphorus pesticide was suspected and the package of Bladan ${ }^{\mathbb{R}}$ was found on the scene, an initial screen test by TLC was done. The pesticide parathion presence was confirmed on the pack found near the victim but not in postmortem samples.

Chromatographic conditions were optimised to provide both short retention times and an adequate peak shape in order to allow the quantification of fenarimol. Ethirimol, a fungicide not used in Portugal, was selected as internal standard. Fig. 1 shows a HPLC chromatogram obtained from a postmortem liver specimen spiked with fenari$\mathrm{mol}(\mathrm{RT}=3.914 \mathrm{~min})$ at $50 \mu \mathrm{g} / \mathrm{g}$ and ethirimol $(\mathrm{RT}=$
$2.097 \mathrm{~min}$ ) at $20 \mu \mathrm{g} / \mathrm{g}$, followed by DAD detection at $225 \mathrm{~nm}$. The UV spectrum of fenarimol and ethirimol is compared to a user-built library containing a standard spectrum of the same compound (Fig. 2).

Calibration curves of fenarimol in blood, liver and kidney samples were linear over a concentration range of $5-250 \mu \mathrm{g} / \mathrm{ml}$, with correlation coefficients $\geq 0.9924$ ( six calibration points in triplicates). Linearity was also observed in the standard curves with a concentration range of 0.06 to $5 \mu \mathrm{g} / \mathrm{ml}(\mathrm{CV}<12)$. Standard curves were constructed by plotting a 1 per year weighted least-squares linear regression of fenarimol to the internal standard peak-area ratios versus the spiked concentration of fenarimol.

The validation results are summarised in Table 1 . Withinday precision was evaluated by replicate analysis $(n=5)$ of spiked blood, liver and kidney samples, at each of five concentrations. The concentrations used were based on the high concentrations of fenarimol found in postmortem
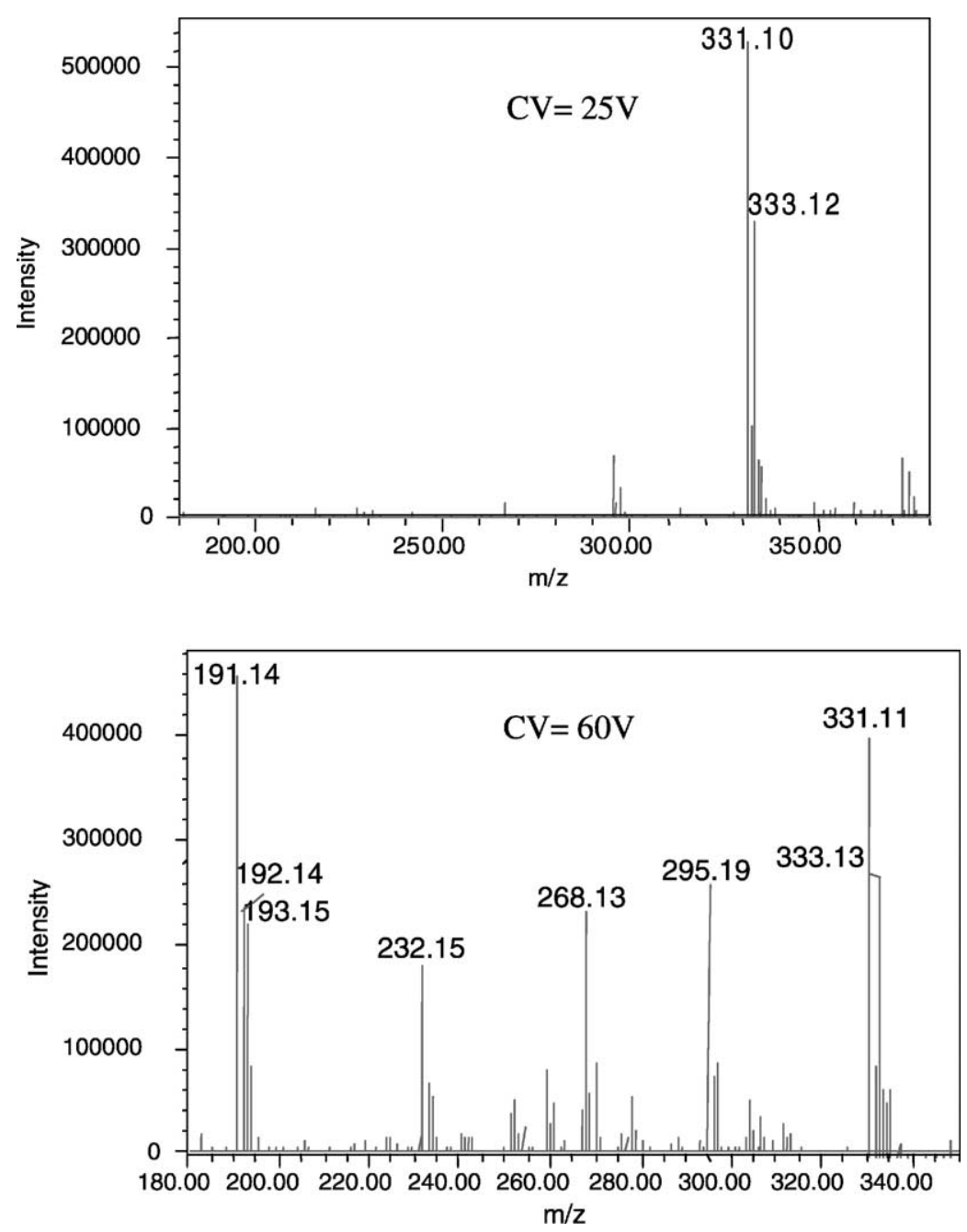

Fig. 3. Positive ES mass spectrum of fenarimol: cone voltage of 25 and $60 \mathrm{~V}$. 
samples. In blood samples, the within-day coefficients of variation $(\% \mathrm{CV})$ ranged between 0.8 and $5.6 \%$, and accuracy between 96.5 and $99.2 \%$. The within-day $\% \mathrm{CV}$ for the liver samples ranged from 1.6 to 4.1 and for the kidney samples the \%CV values were less than $4.6 \%$. Accuracy for liver and kidney samples was in range $92.6-96.8 \%$ and $75.5-$ $96.9 \%$, respectively.

The limits of detection (LOD) were evaluated by analysing drug-free samples spiked with fenarimol at decreasing concentrations, until a response equivalent to three times the background noise was observed. The limits of quantification (LOQ) were determined in the same way by a signal-to-noise of 10. In MSD, SIR mode, the LOD and LOQ for fenarimol in liver samples were of 20 and $60 \mathrm{ng} / \mathrm{g}$, respectively.

The influence of various cone voltage settings on fenarimol fragmentation and the method sensitivity was studied. Fenarimol and the internal standard were analysed by positive electrospray ionization $(\mathrm{ES}+)$, with cone voltage varying from 25 to $60 \mathrm{~V}$. Results of positive ES mass spectrum of fenarimol with a cone voltage of 25 and $60 \mathrm{~V}$ are shown in Fig. 3. Cone voltage fragmentation was used in order to generate some structural information for fenamirol. However, ethirimol could not be fragmented, even at $60 \mathrm{~V}$.

Extracted ion chromatograms of $\mathrm{m} / \mathrm{z}, 332$ and 210 recorded in the single ion recording (SIR) mode for fenarimol and ethirimol, respectively, are presented in Fig. 4.

The toxicological analysis of our reported fatal case showed concentrations of fenarimol in postmortem samples of $1.9 \mathrm{mg} / \mathrm{g}$ in liver, $0.4 \mathrm{mg} / \mathrm{g}$ in kidney and $89.0 \mathrm{mg} / \mathrm{ml}$ in gastric contents. Due to the high concentrations of fenarimol detected in this fatal case, specially in gastric contents, we had to dilute the extracts before injection, obtaining good results with the highly sensitive method used, which was previously validated in the same conditions.

Fenarimol concentrations obtained in this case may not reflect its concentrations at the time of death since the autopsy was performed 3 days after the probable date of death and the victim was found face down in a puddle, which may facilitate possible postmortem redistribution phenomena. The site- and time-dependent variability of postmortem blood and tissue concentrations, as well as the different

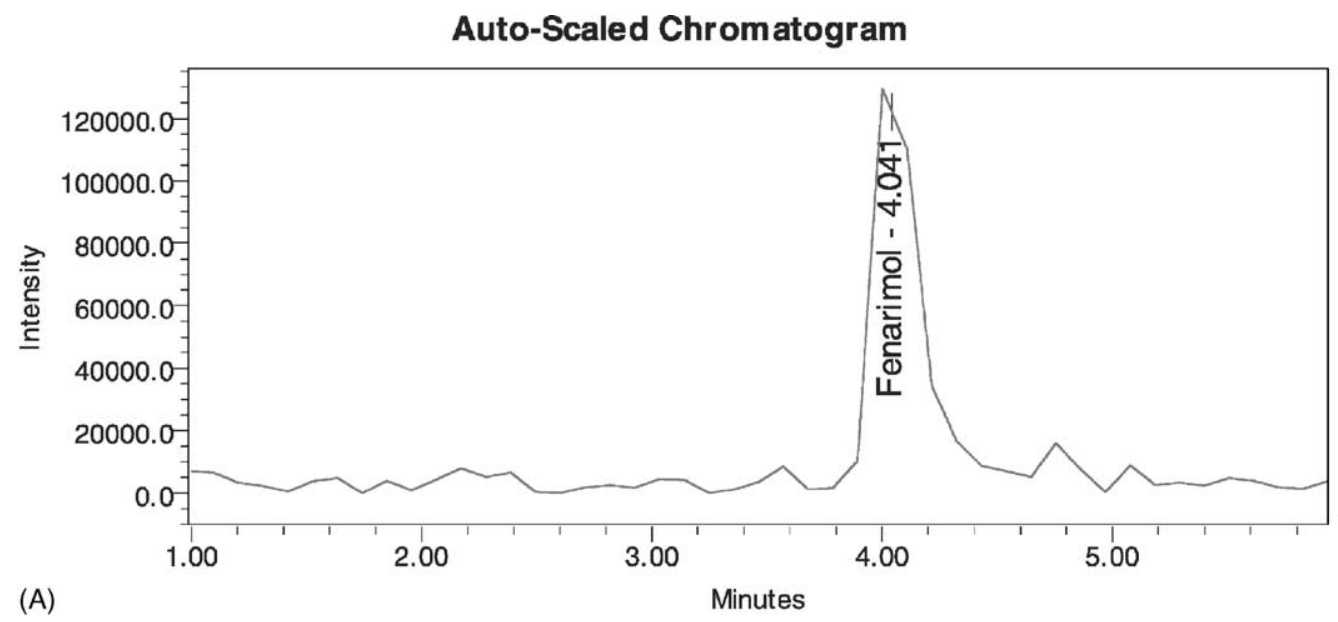

Auto-Scaled Chromatogram

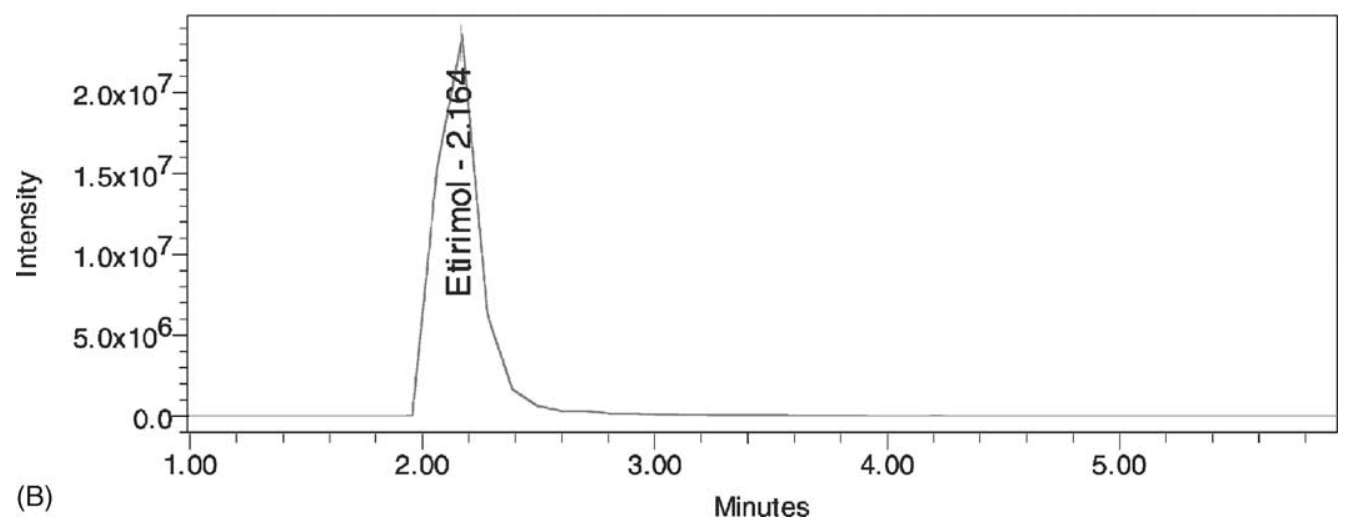

Fig. 4. SIR chromatogram of (A) fenarimol $(\mathrm{m} / \mathrm{z} 332 \mathrm{ES}+, \mathrm{CV}=25 \mathrm{~V})$ and $(\mathrm{B})$ ethirimol $(\mathrm{m} / z 210 \mathrm{ES}+, \mathrm{CV}=25 \mathrm{~V})$. 
postmortem redistribution processes possibly involved have been well documented and reviewed [11-18]. Fenarimol is a highly lipophilic pesticide which, associated to putrefactive changes, [15,19] may be submitted to postmortem redistribution, explaining, in some cases, the increased concentrations in some organs and/or tissues. Accordingly, the high concentration obtained in liver samples $(1.9 \mathrm{mg} / \mathrm{g})$ in this case may reflect postmortem diffusion from gastric residue to the liver $[16,20]$.

Since no other fenarimol fatal cases were found in the literature, it was not possible to compare these results to those of other authors and therefore to interpret the concentrations found with respect to toxic effects.

\section{Conclusion}

DAD produces an UV spectra that can be used for the identification of several compounds through spectral matching. However, some UV spectra of different compounds are quite similar and, in these cases, can not be used for positive compound identification. The ability of DAD to provide information on peak homogeneity combined with mass spectral information such as the pseudo-molecular ion of the molecule simplifies the identification of unknowns and increases confidence in chromatographic peak identification. Acquisition in the SIR mode provides increased sensitive and specificity for target compound analysis as well as linear calibration for compound quantification.

The method described here is linear, precise, accurate, sensitive and specific and can be used in routine forensic investigation.

\section{References}

[1] C.D.S. Tomlin, The Pesticide Manual, 11th ed., British Crop Protection Council, 1997.

[2] Guia dos Produtos Fitofarmacêuticos, Ed. Direcção Geral de Protecção das Culturas, 1997.

[3] M.C. Mateus, A.M. Silva, H.D. Burrows, Enviromental and laboratory studies of the photodegradation of the pesticide fenarimol, J. Photochem. Photobiol. A 80 (1994) 409-416.

[4] M.C. Mateus, A.M. Silva, H.D. Burrows, UV-visible absorption spectra and luminescence of the pesticide fenarimol, Spectrochim. Acta Part A 53 (1997) 2679-2684.
[5] M.C. Mateus, A.M. Silva, H.D. Burrows, Fenarimol solar degradation pathways and photoproducts in aqueous solution, Chemosphere 48 (3) (2002) 363-373.

[6] S.A. Briggs (Ed.), Basic Guide to Pesticides, Taylor and Francis, 1992 (Chapter 4).

[7] H.R. Andersen, A.M. Vinggaard, T.H. Rasmussen et al., Effects of currently used pesticides in assays for estrogenicity androgenicity, and aromatase activity in vitro, Toxicol. Appl. Pharmacol. 179 (1) (2002) 1-12.

[8] M. Paolini, R. Mesirca, L. Pozzetti et al., Genetic and nongenetic biomarkers related to carcinogenesis in evaluating toxicological risk from fenarimol, Mutat. Res. 368 (1) (1996) 27-39.

[9] http://www.dowagro.com/uk/technical/images/rubigan.htmL.

[10] A.C. Moffat, J.V. Jackson, M.S. Moss, Clarke's Isolation and Identification of Drugs in Pharmaceuticals, Body Fluids, and Post-mortem Materials, The Pharmaceutical press, London, 1986.

[11] D.J. Pounder, G.R. Jones, Post-mortem drug redistribution-A toxicological nightmare, Forensic Sci. Int. 45 (1990) 253263.

[12] F.E. Barnhart, J.R. Fogacci, D.W. Reed, Methamphetaminea study of postmortem redistribution, J. Anal. Toxicol. 23 (1999) 69-70.

[13] R.C. Pohland, N.R. Bernhard, Postmortem serum and tissue redistribution of fluoxetine and norfluoxetine in dogs following oral administration of fluoxetine hydrochloride (Prozac), J. Forensic Sci. 42 (5) (1997) 812-816.

[14] B.K. Logan, D. Smirnow, Postmortem distribution and redistribution of morphine in man, J. Forensic Sci. 42 (2) (1997) 221-229.

[15] A.L. Pelissier-Alicot, et al. Mécanismes de la redistribution post-mortem des xénobiotiques: le point sur l'état actual des connaissances. Annales de Toxicologie Analytique, vol. XIII, no. $1,2001$.

[16] D.J. Pounder, J.I. Davies, Zopiclone poisonig: tissue distribution and potencial for postmortem diffusion, Forensic Sci. Int. 65 (1994) 177-183.

[17] D.S. Cook, R.A. Braithwaite, K.A. Hale, Estimating antemortem drug concentrations from postmortem blood samples: the influence of postmortem redistribution, J. Clin. Pathol. 53 (2000) 282-285.

[18] A. Koreeda, K. Yonemitsu et al., Clocapramine-related fatality postmortem drug levels in multiple psychoactive drug poisonig, Forensic Sci. Int. 122 (2001) 48-51.

[19] K. Yonemitsu, D.J. Pounder, Postmortem changes in blood tranycypromine concentration: competing redistribution and degradation effects, Forensic Sci. Int. 59 (2) (1993) 177-184.

[20] D.J. Pounder, C. Fuke et al., Postmortem diffusion of drugs from gastric residue: an experimental study, Forensic Am. J. Forensic Med. Pathol. 17 (1) (1996) 1-7. 